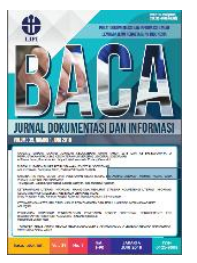

\title{
PROSPEK DAN TANTANGAN INDUSTRI PENERBITAN JURNAL DAN PROSIDING MELALUI TEKNOLOGI E-PUBLISHING DI ERA DIGITAL
}

\author{
Purwadi $^{*}$, Irwansyah ${ }^{2}$ \\ ${ }^{1}$ Biro Kerja Sama, Hukum, dan Humas, Lembaga Ilmu Pengetahuan Indonesia \\ ${ }^{1,2}$ Fakultas Ilmu Sosial dan Ilmu Politik, Universitas Indonesia \\ *Korespondensi: purwadi.lipi@gmail.com
}

Diajukan: 15-05-2019; Direview: 09-02-2020; Diterima: 08-03-2020; Direvisi: 29-05-2020

\begin{abstract}
This study aims to determine: (1) the publication of journals and proceedings using e-publishing technology; (2) the prospect of the industry in publishing journals and proceedings in the digital era in the Indonesian context; (3) challenges and efforts to disseminate e-journal and e-proceeding. The study approach is qualitative with the literature review method. The results of the study show that: (1) the use of e-publishing technology is an important part of the publication of e-journal and e-proceeding in the future, which is more flexible, efficient and effective than before; (2) the prospect of publishing the journal and proceedings in the future is fairly bright because publishing technology is more sophisticated, so it encourages better publishing products in terms of types and numbers that are increasingly numerous, interactive, easily accessible, utilizing artificial intelligence, until finally all archiving has made use of big data; (3) the challenges in publishing journals and online proceedings are the competence of human resources, many competitors in this business, the quality of publications tend to be ignored, the disruption of professions, and many abrupt publishers. Meanwhile, digital technology has made the dissemination of journals and proceedings easier, faster and more efficient because they do not involve many parties anymore. E-publishing also reduces the bureaucracy of publishing journals and proceedings, such as not requiring printed correspondence, but simply through e-mail or tools in OJS or OCS applications.
\end{abstract}

\begin{abstract}
ABSTRAK
Kajian ini bertujuan untuk mengetahui: (1) penerbitan jurnal dan prosiding menggunakan teknologi $e$ publishing, (2) prospek industri penerbitan jurnal dan prosiding di era digital dalam konteks Indonesia; (3) tantangan dan upaya diseminasi e-journal dan e-proceeding. Pendekatan kajian adalah kualitatif dengan metode studi literatur. Hasil kajian menunjukkan bahwa: (1) pemanfaatan teknologi e-publishing menjadi bagian penting dalam penerbitan e-journal dan e-proceeding ke depan, yang mana lebih fleksibel, efisien, dan efektif dibandingkan sebelumnya; (2) prospek industri penerbitan jurnal dan prosiding di masa mendatang terbilang cerah karena teknologi penerbitan lebih canggih, sehingga lebih mendorong produk penerbitan yang lebih baik dari segi jenis dan jumlah yang semakin banyak, interaktif, mudah diakses, memanfaatkan kecerdasan buatan, sampai akhirnya seluruh pengarsipan telah memanfaatkan big data; (3) tantangan dalam penerbitan jurnal dan prosiding secara online adalah kompetensi sumber daya manusia, kompetitor yang banyak dalam bisnis ini, kualitas terbitan cenderung diabaikan, disrupsi profesi, dan banyak muncul penerbit abal-abal. Sedangkan teknologi digital telah membuat diseminasi jurnal dan prosiding menjadi lebih mudah, cepat, dan efisien karena tidak melibatkan banyak pihak lagi. E-publishing juga mengurangi birokrasi penerbitan jurnal dan prosiding, seperti tidak memerlukan surat-menyurat cetak, tetapi cukup melalui email atau tools dalam aplikasi OJS maupun OCS.
\end{abstract}

Keywords: Publishing; Journal; Proceeding, Open Journal System; Open Conference Sysrem; Digital age

\section{PENDAHULUAN}

Perkembangan teknologi informasi dan komunikasi yang cepat membawa perubahan drastis bagi masyarakat dan industri. Kehidupan masyarakat kini berada di era baru yang 
berbeda dari era sebelumnya. Era masyarakat dan industri sendiri telah terbagi-bagi ke beberapa fase dalam sejarahnya (Fukuyama, 2018; Schwab, 2016). Ada lima tahapan dalam perkembangan masyarakat (society), dimulai dari: (1) society 1.0, sebagai kelompok orang yang berburu dan berkumpul dalam kehidupan yang berdampingan secara harmonis dengan alam; (2) society 2.0, yang membentuk kelompok-kelompok berdasarkan sistem pertanian, peningkatan organisasi dan pembangunan bangsa; (3) society 3.0, masyarakat yang mempromosikan industrialisasi melalui revolusi industri, memungkinkan produksi massal; (4) society 4.0, masyarakat informasi dengan kesadaran peningkatan nilai tambah dengan menghubungkan aset tidak berwujud sebagai jaringan informasi; (5) society 5.0, masyarakat informasi yang dibangun di atas society 4.0 dan saat ini sedang terjadi, bertujuan untuk masyarakat yang berpusat pada manusia yang makmur (Fukuyama, 2018).

Schwab (2016) menjelaskan revolusi industri mempunyai empat tahapan. Pertama, revolusi industri 1.0 yang merentang dari sekitar tahun 1760-1840. Revolusi industri ini dipicu oleh pembangunan jalur kereta api dan penemuan mesin uap yang mengantarkan pada produksi mekanik. Kedua, revolusi industri 2.0, yang dimulai pada akhir abad ke-19 dan awal abad ke20. Revolusi industri tersebut memungkinkan produksi massal yang didorong oleh munculnya listrik dan jalur perakitan. Ketiga adalah revolusi industri 3.0, yang dimulai pada 1960-an. Biasanya disebut revolusi komputer atau digital karena industri dikatalisis oleh pengembangan semikonduktor, komputasi mainframe (1960-an), komputasi pribadi (1970-an dan 1980-an) dan Internet (1990-an). Keempat, revolusi industri 4.0, yang ditandai dengan sistem cyber-physical. Revolusi ini dimulai pada pergantian abad 21 dan dibangun di atas revolusi digital. Hal ini ditandai dengan mobile Internet yang lebih banyak dan di mana-mana, dengan sensor yang lebih kecil, kuat, dan murah, serta adanya kecerdasan buatan dan pembelajaran mesin. Revolusi industri 4.0 menciptakan dunia di mana sistem manufaktur virtual dan fisik secara global saling bekerja sama dengan cara yang fleksibel (Schwab, 2016).

Perkembangan masyarakat dan industri yang telah mencapai industri 4.0 dan society 5.0 berimbas pada industri penerbitan. Hal tersebut juga terjadi pada industri dan teknologi penerbitan jurnal dan prosiding, di mana keduanya telah beralih ke sistem penerbitan elektronik (e-publishing). Teknologi e-publishing ini sangat dibutuhkan oleh masyarakat, khususnya generasi milenial. Lyons (2004) mengatakan bahwa generasi milenial banyak menggunakan teknologi komunikasi instan yang berbasiskan penggunaan perangkat ponsel pintar, seperti email, short message service (SMS), aplikasi pesan online, dan media sosial. Generasi milenial sangat tergantung pada teknologi pada awal hidup mereka dibanding generasi-generasi sebelumnya (Smith \& Nichols, 2015).

Generasi milenial lahir pada era internet telah mendominasi era digital. Dalam pandangan generasi milenial, penggunaan teknologi internet menjadi kebutuhan pokok dan kebanyakan mereka memiliki media sosial (Pew Research Center, 2010). Keberadaan teknologi $e$ publishing ini sangat membantu generasi milenial dalam penerbitan jurnal elektronik (ejournal) dan prosiding elektronik (e-proceeding). Kedua produk digital tersebut membawa kemudahan akses data dan informasi lengkap bagi penggunanya. Dari aspek diseminasi, publikasi ilmiah melalui sistem elektronik menjadi lebih cepat, efisien, dan efektif.

Teknologi e-publishing pada dasarnya memainkan peran penting khususnya untuk industri jurnal dan prosiding di era digital ini. Perubahan tatanan media tradisional ke media baru berdampak pada perubahan tatanan sosial di masyarakat, dan hal tersebut digambarkan sebagai situasi hibridisasi atau percampuran antara manusia dengan teknologi (Purwadi \& Irwansyah, 2019). Teknologi e-publishing dalam penerbitan jurnal dan prosiding menjadi 
penting dikaji dari berbagai aspek, seperti: (1) bagaimana penerbitan jurnal dan prosiding menggunakan teknologi e-publishing; (2) bagaimana prospek industri penerbitan jurnal dan prosiding di era digital; (3) apa saja tantangan dan upaya diseminasi penerbitan jurnal dan prosiding ke depan.

\section{TINJAUAN PUSTAKA}

\subsection{Industri Penerbitan}

Rambatan (2015) menjelaskan kata "publish" merupakan asal kata "penerbitan". Istilah "penerbitan" muncul di awal tahun 1570, dengan pemahaman dari pekerjaan yang tercetak atau informasi yang tertulis. Menurut European Commission and Skillset Assesment UK (2011) dalam penerbitan merupakan proses produksi dan penyebaran informasi kepada publik. Informasi ini dapat berupa beragam jenis karya dan fokus utamanya adalah menciptakan konten untuk konsumen. Kata "penerbitan" dalam bahasa Inggris sama dengan "publishing", kemudian dari padanan ini, World Intellectual Property Organization (WIPO) melihat kembali pengertian penerbitan dari asal katanya yaitu "publik", sehingga penerbitan merupakan industri yang mendistribusikan konten kepada publik atau khalayak. Ikatan Penerbit Indonesia (IKAPI), mendefinisikan penerbitan sebagai kegiatan yang menggabungkan aktivitas percetakan dalam alur proses penerbitan. Percetakan dilakukan selepas penyuntingan dan pemeriksaan aksara. Kegiatan itu terjadi sebelum pendistribusian hasil terbitan ke distributor, baik secara konvensional atau daring (Rambatan, 2015).

Berdasarkan sejarahnya diketahui bahwa penerbitan muncul ketika ada penemuan teknologi percetakan dari Gutenberg pada tahun 1455, dan peristiwa tersebut menjadi cikalbakal era penerbitan sekarang. Dahulu, penerbitan merupakan industri rumahan saja, namun sejak mesin cetak muncul, penerbitan telah berkembang pesat khususnya pada akhir abad ke18 dan awal abad ke-19 (Keh, 1998). Setelah peristiwa itu, industri penerbitan ini mengalami evolusi. Tercatat ada tiga fase dalam evolusi tersebut. Fase pertama dimulai pada 1980-an, hasil pengembangan riset memunculkan paket perangkat lunak yang memungkinkan publikasi diletakkan di layar komputer dan disimpan sebagai file elektronik. Pada tahap ini, file yang dihasilkan selalu dikirim untuk dicetak dalam bentuk cetak. Fase kedua adalah penerbitan pada pertengahan 1990-an, sejak kemunculan teknologi internet. Perkembangan teknologi internet dan difusi globalnya mendorong keberhasilan konten digital. Kemunculan dan kemudian berkembangnya surat kabar dan majalah online, e-book, e-journal, e-proceeding, dan produk publikasi serupa - yang meyakinkan para ahli bahwa era informasi baru telah dimulai, dan mempengaruhi konsumen menggunakan perangkat digital (seperti ponsel pintar dan tablet) untuk membaca publikasi tersebut. Istilah "e-publishing" mengacu pada distribusi melalui internet, informasi elektronik, dan konten lainnya sebagaimana yang dikatakan oleh Mangani \& Tarrini (2017).

Menurut Kist (1989) dalam Bashorun, Jain, Sebina, \& Kalusopa (2013), teknologi penerbitan merupakan sebuah aplikasi penerbitan dengan memfokuskan proses yang dibantu oleh perangkat komputer, yang dapat menemukan, menangkap, membentuk, dan memperbarui konten informasi, serta menyebarluaskannya kepada khalayak yang dipilih. Ludwick (2000) menggambarkan e-publishing sebagai bahan non-cetak yang diproduksi secara digital. Cuadra (1981) mengidentifikasi dua alat utama yang dapat memfasilitasi e-publishing, yaitu komputer dan jaringan komunikasi. Komputer memfasilitasi proses produksi, sementara distribusi ditangani melalui jaringan komunikasi, memungkinkan pengguna untuk mengakses data yang dihasilkan secara elektronik. Teknologi e-publishing menggunaan perangkat elektronik dalam 
semua aspek produksi, manajemen, dan distribusi informasi primer dan sekunder, serta dalam menyimpan dan mengambil informasi secara online (Bashorun, et al., 2013).

\subsection{E-Journal dan E-Proceeding}

E-journal merupakan jurnal, majalah, e-zine, webzine, buletin atau jenis publikasi serial elektronik apa pun yang tersedia melalui Internet dan dapat diakses menggunakan berbagai teknologi (Arora, 2001 dalam Bashorun et al., 2013). Sedangkan, e-proceeding adalah kumpulan artikel atau makalah dari penyelenggaraan sebuah konferensi ilmiah yang dipublikasikan secara online (Nashihuddin \& Aulianto, 2017). Berangkat dari definisi ejournal dan e-proceeding tersebut, maka menghadirkan aplikasi untuk menerbitkan publikasi tersebut, misalnya Open Journal Systems (OJS) untuk e-journal dan Open Conference Systems (OCS) untuk e-proceeding (PKP, 2008).

OJS merupakan platform atau aplikasi manajemen jurnal dan penerbitan online yang pertama kali diluncurkan sejak tahun 2002, sebagai perangkat lunak sumber terbuka (open source) yang didistribusikan secara bebas oleh Public Knowledge Project (PKP) (Willinsky, 2005 dalam Edgar \& Willinsky, 2010). Perangkat lunak ini telah dikembangkan sebagai bagian dari program penelitian PKP di University of British Columbia (UBC) di Vancouver, Kanada, di bawah arahan John Willinsky, dengan partisipasi selanjutnya oleh Simon Fraser University Library, the Canadian Centre for Studies in Publishing, dan Stanford University. Aplikasi ini dirancang untuk mengelola alur kerja jurnal, mulai dari penyerahan naskah hingga ulasan ke pekerjaan editorial dan kemudian publikasi, sambil menawarkan cara yang siap untuk menerbitkan edisi online dan mengelola biaya operasional jurnal dengan lebih baik (Willinsky, 2006 dalam Edgar \& Willinsky, 2010). Aplikasi OJS dirancang untuk mengurangi waktu dan energi yang ditujukan untuk tugas-tugas klerikal dan manajerial yang terkait dengan pengeditan jurnal, serta meningkatkan penyimpanan catatan dan efisiensi proses editorial. OJS berusaha meningkatkan kualitas publikasi jurnal ilmiah melalui sejumlah inovasi, dari membuat kebijakan jurnal lebih transparan hingga meningkatkan pengindeksan (Willinsky, Stranack, Smecher, \& MacGregor, 2010). Beberapa fitur yang dimiliki OJS, antara lain: (1) OJS di-install secara lokal dan dikontrol secara lokal; (2) editor mengkonfigurasi persyaratan, bagian, proses peninjauan, dan lainnya; (3) pengiriman online, ulasan doubleblind, dan manajemen semua konten; (4) modul berlangganan dengan akses terbuka tertunda dan opsi akses tidak terbuka; (5) pengindeksan konten yang komprehensif; (6) alat bacaan untuk konten, berdasarkan bidang dan pilihan editor; (7) pemberitahuan email dan kemampuan komentar untuk pembaca; (8) dukungan bantuan online yang peka dengan konteks lengkap; (9) modul pembayaran untuk menerima biaya jurnal, sumbangan, dan lainnya (Willinsky et al., 2010).

OCS adalah alat penerbitan web gratis yang akan membuat kehadiran web lengkap untuk konferensi ilmiah. Aplikasi OCS bersifat open source, di mana dalam pengelolaan fitur dan kontennya dapat disesuaikan dengan kebutuhan penyelenggaraan konferensi (Nashihuddin \& Aulianto, 2017). OCS akan memungkinkan untuk: (1) membuat situs web konferensi; (2) mengirim informasi dan menulis makalah; (3) mengirim abstrak dan menerima makalah; (4) mengedit makalah; (5) memproses pasca-konferensi dan makalah yang dapat ditelusuri; (6) mem-posting makalah beserta dataset; (7) membuat daftar peserta; (8) mengintegrasikan diskusi online pasca-konferensi (PKP, 2014). Aplikasi OCS dapat diunduh secara gratis melalui website PKP (Purbarani, Wisesa, \& Wibisono, 2015). OCS menyediakan fitur yang cukup lengkap, mulai dari proses registrasi peserta, pengaturan sistem, hingga pengawasan 
kegiatan oleh direktur konferensi. Penyelenggara konferensi dapat menggunakan OCS untuk kegiatan tahunan dan berkala tanpa harus membangun dan mengembangkan sistem lagi (Purbarani et al., 2015).

\section{METODE}

Penelitian ini menggunakan pendekatan kualitatif, dengan teknik studi literatur (literature review). Literature review merupakan survei artikel ilmiah, buku, dan sumber lain yang relevan dengan masalah tertentu, bidang penelitian, atau teori, dan dengan demikian, memberikan deskripsi, ringkasan, dan evaluasi dari berbagai karya (Ramdhani, Rahmdhani, \& Amin, 2014). Menurut Hart (1998); Cronin, et al. (2008) dalam Ramdhani et al. (2014), literature review adalah ringkasan objektif, menyeluruh dan analisis kritis dari artikel ilmiah penelitian yang tersedia dan literatur non-penelitian yang relevan pada topik yang sedang dikaji. Menurut Steward (2004) dalam Bolderston (2008), karakteristik literature review: (1) komprehensif, yakni bukti harus dikumpulkan dari semua sumber yang relevan; (2) penggunaan referensi secara penuh, sehingga memungkinkan orang lain untuk mengikuti jalan pikiran penulis dari awal ke kesimpulan artikel kajian; (3) selektif, yaitu menggunakan strategi pencarian yang sesuai untuk menemukan bukti utama yang cocok dengan topik; (4) relevan, adalah fokus pada data terkait; (5) sintesis, yakni melakukan sintesis untuk tema dan gagasan utama; (6) seimbang, antara berbagai ide dan pendapat; (7) kritis, dalam penilaian literatur; (8) analitis, yakni mengembangkan ide dan pemahaman baru untuk topik artikel kajian. Berikut ini beberapa artikel jurnal dan buku yang menjadi bahan literature review penelitian (Tabel 1).

Tabel 1. Bahan Literatur Penelitian

\begin{tabular}{|c|c|c|c|}
\hline No. & Penulis & Jenis Literar & Judul Artikel \\
\hline \multicolumn{4}{|c|}{ Teknologi e-publishing (OJS \& OCS) } \\
\hline 1 & PKP (2008) & Buku & OJS/OCS Quick Reference \\
\hline 2 & Edgar \& Willinsky (2010) & Artikel Jurnal & $\begin{array}{l}\text { A Survey of Scholarly Journals Using Open } \\
\text { Journal Systems }\end{array}$ \\
\hline 3 & Arief \& Handoko (2017) & Buku & Jurnal Online dengan Open Journal System \\
\hline \multicolumn{4}{|c|}{ Prospek Penerbitan Jurnal dan Prosiding di Era Digital } \\
\hline 4 & $\begin{array}{l}\text { Bashorun, Jain, Sebina, \& } \\
\text { Kalusopa (2013) }\end{array}$ & Artikel Jurnal & $\begin{array}{l}\text { The Evolution of Electronic Publishing: A } \\
\text { Literature Review }\end{array}$ \\
\hline 5 & Ridwan (2015) & Artikel Jurnal & $\begin{array}{l}\text { Application of Electronic Scholarly Publishing in } \\
\text { Digital Age: Prospects and Challenges in } \\
\text { Nigerian Universities }\end{array}$ \\
\hline 6 & $\begin{array}{l}\text { Velmurugan \& } \\
\text { Radhakrishnan (2015) }\end{array}$ & Artikel Jurnal & $\begin{array}{l}\text { Electronic Publishing: A Powerful Tool for } \\
\text { Academic Institutions in the Electronic } \\
\text { Environment }\end{array}$ \\
\hline \multicolumn{4}{|c|}{ Tantangan dan Upaya Diseminasi Penerbitan Jurnal dan Prosiding } \\
\hline 7 & Clarke \& Kingsley (2008) & Artikel Jurnal & $\begin{array}{l}\text { E-Publishing's Impacts on Journals and Journal } \\
\text { Articles }\end{array}$ \\
\hline 8 & Rambatan (2015) & Buku & $\begin{array}{l}\text { Ekonomi Kreatif: Rencana Pengembangan } \\
\text { Penerbitan Nasional 2015-2019 }\end{array}$ \\
\hline 9 & Mangani \& Tarrini (2017) & Artikel Jurnal & $\begin{array}{l}\text { Who survives a recession? Specialization against } \\
\text { diversification in the digital publishing industry }\end{array}$ \\
\hline 10 & Siler (2017) & Artikel Jurnal & $\begin{array}{l}\text { Future Challenges and Oppotunities in Academic } \\
\text { Publishing }\end{array}$ \\
\hline
\end{tabular}

Data yang telah terkumpul, kemudian dipilih dan dikelompokkan sesuai pokok bahasan, yaitu: (1) teknologi e-publishing untuk penerbitan e-journal dan e-proceeding; (2) prospek 
industri penerbitan jurnal dan prosiding di era digital; (3) tantangan dan upaya diseminasi penerbitan jurnal dan prosiding. Setelah itu, setiap literatur di atas, dianalisis secara deskriptif. Hasil analisis menjadi bahan pembahasan dan kesimpulan penelitian.

\section{HASIL DAN PEMBAHASAN}

\subsection{Penerbitan E-Journal dan E-Proceeding}

\subsubsection{Penerbitan E-Journal dengan OJS}

Salah satu aplikasi untuk penerbitan e-journal adalah dengan OJS. Dengan aplikasi OJS, proses penerbitan lebih fleksibel, efisien, dan efektif karena memanfaatkan teknologi epublishing.

- Fleksibel, karena OJS dapat memangkas proses birokrasi yang panjang di institusi atau korporasi dalam penerbitan jurnal. Pemangkasan ini dilakukan secara online melalui teknologi, mulai dari submit naskah hingga penerbitan artikel jurnal (Arief \& Handoko, 2017; Edgar \& Willinsky, 2010).

- Efisien, karena menghemat dana untuk penerbitan yang berbiaya tinggi. Dengan OJS, pendistribusian pengetahuan informasi jurnal kepada publik lebih efekif, karena dilakukan secara online (Edgar \& Willinsky, 2010).

Terkait hal tersebut, Arief \& Handoko (2017) \& PKP (2008) menjelaskan perbandingan antara penerbitan secara analog dan online menggunakan OJS (Gambar 1).

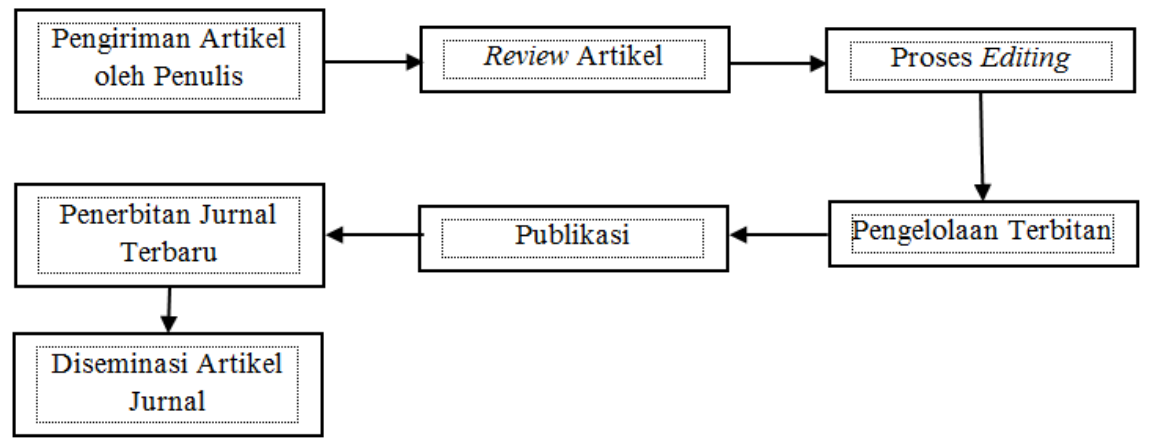

Gambar 1. Penerbitan jurnal secara analog/hybrid

Gambar 1 menunjukkan bahwa proses penerbitan jurnal dapat dikategorikan dalam dua ruang, yaitu analog dan hybrid (percampuran teknologi). Pertama untuk ruang analog, terjadi sebelum kehadiran teknologi komputer dan internet (sebelum revolusi industri 3.0). Di ruang analog, peran manusia dominan dengan bantuan teknologi tradisional. Kedua adalah ruang hybrid, di mana dalam penerbitan jurnal ada percampuran antara manusia dan teknologi digital yang seimbang. Dalam hal ini, peran teknologi ada pada pengelolaan terbitan, publikasi, dan penerbitan jurnal itu sendiri. Setelah beralih ke penerbitan jurnal pada era revolusi industri 4.0, maka proses penerbitannya berubah drastis, yakni dengan meminimalkan keterlibatan teknologi analog dan manusia. Hal tersebut dapat dilihat pada Gambar 2. 


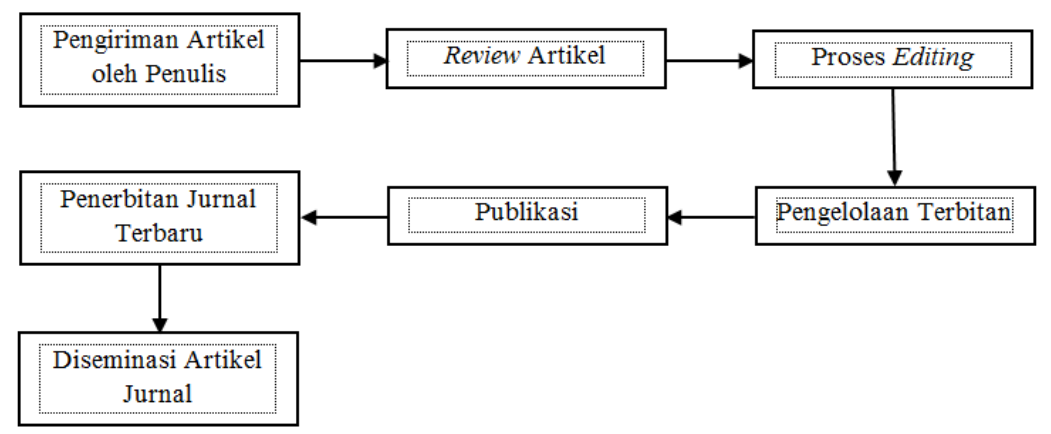

Gambar 2. Proses penerbitan jurnal secara digital/online

Gambar 2 menunjukkan bahwa setiap proses dalam industri penerbitan jurnal berada dalam ruang digital, menggunakan aplikasi OJS. OJS mempunyai fitur yang memadai untuk penerbitan jurnal secara online, terkoneksi dengan beragam mesin pencari (search engine), sehingga memudahkan pencarian dan identifikasi hasil pencarian artikel (Arief \& Handoko, 2017).

\subsubsection{Penerbitan E-Proceeding dengan OCS}

Prosiding merupakan bagian dari penerbitan ilmiah kegiatan konferensi atau seminar ilmiah. Perkembangan industri dan teknologi penerbitan prosiding seiring dengan perkembangan penerbitan jurnal. Fase industrinya terbagi menjadi fase analog, hybrid, dan digital. E-proceeding dibangun dengan aplikasi OCS, yang membuat proses penerbitan prosiding hampir secara keseluruhan berada di ruang digital. Gambar 3 menunjukkan proses penerbitan e-proceeding melalui OCS.

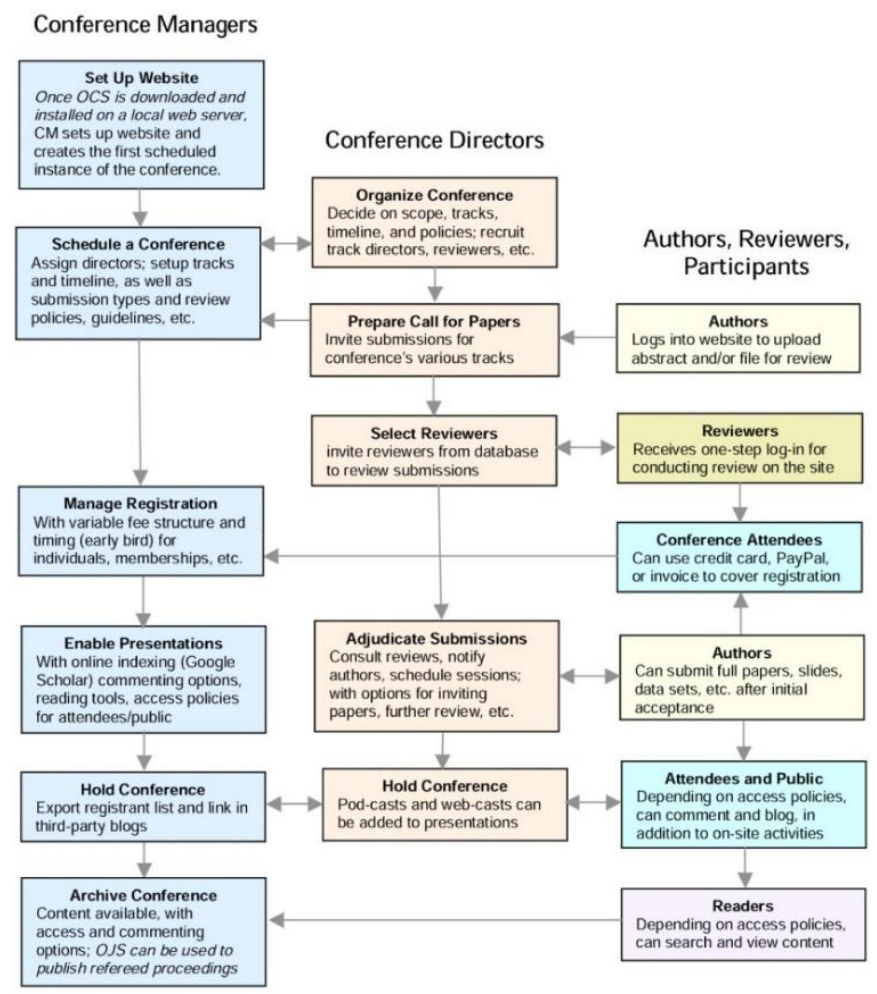

Gambar 3. Proses penerbitan e-proceeding dengan OCS (Sumber: PKP, 2008) 
Gambar 3 menunjukkan bahwa OCS memberikan fasilitas kepada penggunanya sebagai penulis, reviewer, peserta, direktur konferensi, dan manajer konferensi.

- Penulis berperan mengirimkan abstrak dan makalah, mengeditnya, jika perlu, dan membaca saran dari reviewer.

- Reviewer berperan meninjau, membaca abstrak dan makalah, menulis komentar dan rekomendasi untuk memutuskan suatu makalah diterima atau ditolak.

- Peserta (non-penulis) dapat berperan sebagai pembaca sekaligus komentator dari makalah yang ada.

- Direktur konferensi berperan sebagai pengorganisasi, fasilitator pemanggilan makalah, menyeleksi reviewer, memutuskan hasil makalah, dan menyelenggarakan konferensi.

- Manajer konferensi berperan membuat situs web konferensi, membuat jadwal konferensi, mengatur registrasi, menyediakan pengindeksan makalah, membantu penyelenggaraan konferensi, menerbitkan dan mengarsipkan makalah sebagai e-proceeding (PKP, 2008).

\subsection{Prospek Industri Penerbitan Jurnal dan Prosiding}

Sebelum membahas tentang prospek industri penerbitan jurnal dan prosiding, terlebih dahulu dijelaskan tentang kondisi penerbitan terdahulu, sekarang, dan masa depan. Terkait hal tersebut, kondisi ini menjelaskan tentang revolusi penerbitan 500 tahun lalu oleh Johannes Gutenberg -- mulai dari penggunaan mesin cetak hingga memasuki era komputer, internet, dan media digital (Bashorun et al., 2013). Tabel 2 menunjukkan perbandingan tentang kondisi penerbitan jurnal dan prosiding menurut Bashorun et al (2013), Ridwan (2015), dan Velmurugan \& Radhakrishnan (2015).

Tabel 2. Perbandingan Kondisi Penerbitan Jurnal dan Prosiding

\begin{tabular}{|c|c|c|c|}
\hline No. & Dahulu & Sekarang & Masa Depan \\
\hline 1 & $\begin{array}{l}\text { Penggunaan teknologi masih } \\
\text { tradisional dan analog }\end{array}$ & $\begin{array}{l}\text { Teknologi masih hybrid atau } \\
\text { percampuran antara analog } \\
\text { dan digital, contohnya OJS } \\
\text { dan OCS }\end{array}$ & $\begin{array}{l}\text { Teknologi digital yang lebih } \\
\text { canggih dengan keterlibatan } \\
\text { manusia sudah minimal }\end{array}$ \\
\hline 2 & $\begin{array}{l}\text { Produk cetak dan terpaku } \\
\text { pada bentuk tertentu }\end{array}$ & $\begin{array}{l}\text { Produk e-journal dan } e- \\
\text { proceeding }\end{array}$ & $\begin{array}{l}\text { Produk digital yang lebih } \\
\text { canggih, bahkan interaktif. } \\
\text { Produk masa depan juga } \\
\text { mendorong lebih banyak jumlah } \\
\text { serta jenis jurnal dan prosiding }\end{array}$ \\
\hline 3 & $\begin{array}{l}\text { Proses penerbitan } \\
\text { memerlukan dukungan } \\
\text { banyak orang, dengan } \\
\text { beragam profesi }\end{array}$ & $\begin{array}{l}\text { Proses penerbitan lebih } \\
\text { sederhana dan keterlibatan } \\
\text { orang lebih sedikit }\end{array}$ & $\begin{array}{l}\text { Lebih mendorong penggunakan } \\
\text { teknologi secara penuh }\end{array}$ \\
\hline 4 & $\begin{array}{l}\text { Langkah-langkah dalam } \\
\text { penerbitan bersifat birokratis } \\
\text { dan memerlukan step by step } \\
\text { tertentu seperti surat- } \\
\text { menyurat, sehingga proses } \\
\text { penerbitan menjadi lama } \\
\text { atau dalam kurun waktu } \\
\text { tertentu }\end{array}$ & $\begin{array}{l}\text { Proses penerbitan lebih } \\
\text { sederhana dan waktu yang } \\
\text { lebih cepat }\end{array}$ & $\begin{array}{l}\text { Proses penerbitan berbasis } \\
\text { teknologi yang lebih canggih } \\
\text { dan lebih cepat lagi dari } \\
\text { sebelumnya }\end{array}$ \\
\hline 5 & Artikel jurnal dan prosiding & Artikel jurnal dan prosiding & Akses artikel jurnal dan \\
\hline
\end{tabular}




\begin{tabular}{|c|l|l|l|}
\hline & $\begin{array}{l}\text { terbatas jarak ruang dan } \\
\text { waktu untuk mengaksesnya }\end{array}$ & $\begin{array}{l}\text { dapat diakses secara mudah } \\
\text { dengan tanpa ada jarak } \\
\text { ruang dan waktu }\end{array}$ & $\begin{array}{l}\text { prosiding sudah interaktif dan } \\
\text { tanpa batasan ruang dan waktu }\end{array}$ \\
\hline 6 & $\begin{array}{l}\text { Karena artikel jurnal dan } \\
\text { prosiding berbentuk cetak, } \\
\text { maka sistem pencarian lebih } \\
\text { susah atau kurang mudah } \\
\text { dan memerlukan bantuan } \\
\text { orang lain }\end{array}$ & $\begin{array}{l}\text { Artikel jurnal dan prosiding } \\
\text { terhubung ke Internet, } \\
\text { sehingga dapat dicari lewat } \\
\text { mesin pencari }\end{array}$ & $\begin{array}{l}\text { Sistem pencarian lebih canggih } \\
\text { lagi dan bisa mempergunakan } \\
\text { kecerdasan buatan }\end{array}$ \\
\hline 7 & $\begin{array}{l}\text { Artikel jurnal dan prosiding } \\
\text { masih membutuhkan } \\
\text { perpustakaan untuk } \\
\text { penyimpanan, seperti: rak, } \\
\text { ruangan, serta petugas } \\
\text { pengelolanya }\end{array}$ & $\begin{array}{l}\text { Tidak membutuhkan } \\
\text { perpustakan sebagai ruang } \\
\text { penyimpanan }\end{array}$ & $\begin{array}{l}\text { yakni tidak memerlukan } \\
\text { perpustakaan sebagai } \\
\text { penyimpanan, namun teknologi } \\
\text { penyimpanan akan lebih } \\
\text { canggih lagi dengan } \\
\text { pengembangan big data }\end{array}$ \\
\hline 8 & $\begin{array}{l}\text { Era pra revolusi industri } \\
\text { hingga revolusi industri 3.0 }\end{array}$ & Era revolusi industri 4.0 & $\begin{array}{l}\text { Era revolusi industri 4.0 dan } \\
\text { konsep revolusi industri } \\
\text { selanjutnya }\end{array}$ \\
\hline 9 & $\begin{array}{l}\text { Society 1.0 hingga society } \\
3.0\end{array}$ & $\begin{array}{l}\text { Society 4.0 dan awal society } \\
5.0\end{array}$ & $\begin{array}{l}\text { Society 5.0 dan konsep society } \\
\text { lanjutan atau konsep lainnya } \\
\text { lagi }\end{array}$ \\
\hline
\end{tabular}

Sumber: Data olah penulis dari berbagai sumber

Tabel 2 menunjukkan bahwa perkembangan industri dan teknologi penerbitan jurnal dan prosiding mengalami perkembangan secara signifikan (ke arah yang lebih baik). Hal tersebut terlihat dari indikator : (1) eksploitasi yang lebih besar dan pemanfaatan kemampuan multimedia; (2) berbagai model penerbitan berdampingan dan terus berkembang; (3) penerbit mengubah peran tradisionalnya menjadi penyedia layanan elektronik dan online; (4) institusi depositori akan diperkuat dan menjadi lebih popular; (5) peneliti dan penulis menjadi pemangku kepentingan utama dalam penerbitan (Velmurugan \& Radhakrishnan, 2015). Kehadiran teknologi e-publishing mendorong produk penerbitan yang lebih baik, interaktif, dan mudah diakses. Prospek industri penerbitan dianggap lebih relevan dengan kondisi saat ini sehingga dapat menjadi acuan dalam pengembangan penerbitan e-journal dan e-proceeding di Indonesia.

\subsection{Tantangan dan Upaya Diseminasi Penerbitan Jurnal dan Prosiding}

Menurut Rambatan (2015), Clarke \& Kingsley (2008), Mangani \& Tarrini (2017), \& Siler (2017) ada beberapa tantangan dalam penerbitan jurnal dan prosiding online, yaitu: (1) kompetensi sumber daya manusia (SDM); (2) kompetitor dalam bisnis penerbitan online; (3) kualitas terbitan yang kurang terukur dengan baik atau cenderung terabaikan; (4) disrupsi profesi dalam industri penerbitan jurnal dan prosiding; (5) banyaknya penerbit predator (abalabal), yang menyebabkan industri penerbitan online semakin mudah tanpa adanya peraturan dan kebijakan penerbitan yang jelas. Beberapa tantangan tersebut dijelaskan sebagai berikut.

- Permasalahan SDM terkait dengan kemampuan mengoperasionalkan teknologi penerbitan jurnal dan prosiding secara online masih belum banyak. 
- Kemudahan untuk mendapatkan aplikasi OJS dan OCS berdampak pada kemudahan penerbitan jurnal dan proseding online - sehingga muncul kompetitor dalam industri penerbitan

- Munculnya kompetitor akan mengurangi kualitas terbitan, karena dengan sistem online, jurnal dan prosiding lebih mudah diterbitkan.

- Disrupsi profesi, adanya digitalisasi dalam dunia penerbitan menyebabkan terancamnya berbagai profesi, seperti pergantinan staf administrasi penerbitan dikurangi karena sudah terotomasi dengan sistem, dan petugas perpustakaan/pustakawan diganti dengan sistem online (yang tidak lagi memerlukan penyimpanan dan layanan koleksi secara fisik).

- Kemudahan penerbitan online berdampak pada maraknya penerbit jurnal dan prosiding abal-abal yang tidak menjamin kredibilitasnya.

Velmurugan \& Radhakrishnan (2015) juga menjelaskan tantangan atau kekurangan lain dalam penerbitan jurnal dan prosiding online, yaitu: (a) pembaca harus mengakses artikel melalui koneksi internet yang kadang-kadang jaringannya lambat (khususnya untuk file yang berukuran besar menjadi susah di-download); (b) jurnal maupun prosiding online dianggap sebagai sesuatu yang tidak permanen dan mudah rusak atau menghilang dari dunia maya; (c) pembaca yang tidak memiliki perangkat yang mudah dibawa, seperti laptop, tablet, smartphone, dan sejenisnya akan kesulitan membaca file terbitan ketika bepergian.

Diseminasi terbitan jurnal dan prosiding dapat dilakukan secara analog dan digital. Untuk cara analog melalui cara: (1) konferensi atau seminar ilmiah, diseminasinya terletak pada paparan presentasi artikel (yang telah terbit di jurnal atau prosiding); (2) pelatihan publikasi/penulisan, dari pelatihan biasanya dihasilkan artikel sebagai karya ilmiah dan diterbitkan di jurnal atau prosiding; (3) diseminasi melalui layanan koleksi perpustakaan dengan bantuan petugas perpustakaan. Sedangkan cara digital, dilakukan dengan cara indeksasi terbitan ke database pengindeks global seperti Google Scholar, Scopus, DOAJ, Sinta, dsb. Indeksasi tersebut dapat meningkatkan reputasi penulis dan artikel jurnal, serta meningkatan keilmuan bidang tertentu.

\section{KESIMPULAN}

Era digital yang berkaitan erat dengan revolusi industri 4.0 dan society 5.0 telah mengubah industri penerbitan jurnal dan prosiding di dunia dan Indonesia. Berdasarkan pembahasan di atas, dapat disimpulkan: (1) pemanfaatan teknologi e-publishing menjadi bagian penting dalam penerbitan e-journal dan e-proceeding di masa mendatang, yang lebih fleksibel, efisien dan efektif; (2) prospek industri penerbitan jurnal dan prosiding ke depan dianggap lebih baik dengan teknologi yang lebih canggih; (3) tantangan dalam penerbitan jurnal dan prosiding secara online perlu segera dicari solusinya. Prinsipnya bahwa e-publishing dapat mengurangi birokrasi dalam penerbitan jurnal dan prosiding, komunikasi dalam penerbitan dapat melalui email yang terdaftar di aplikasi OJS maupun OCS. 


\section{DAFTAR PUSTAKA}

Arief, I., \& Handoko, H. 2017. Jurnal Online dengan Open Journal System. Padang: LPTIK Universitas Andalas.

Bashorun, M. T., Jain, P., Sebina, P. M., \& Kalusopa, T. 2013. The Evolution of Electronic Publishing: A Literature Review. Transnational Journal of Science and Technology, 3(4), 1132.

Bolderston, A. 2008. Writing an Effective Literature Review. Journal of Medical Imaging and Radiation Sciences Journal, 39, 86-92. https://doi.org/10.1016/j.jmir.2008.04.009

Clarke, R., \& Kingsley, D. 2008. E-Publishing's Impacts on Journals and Journal Articles. Journal of Internet Commerce, 7(1), 120-151. https://doi.org/10.1080/15332860802004410

Edgar, B. D., \& Willinsky, J. 2010. A Survey of Scholarly Journals Using Open Journal Systems. Scholarly and Research Communication, 1(2), 1-22. https://doi.org/10.22230/src.2010v1n2a24

Fukuyama, M. 2018. Society 5.0: aiming for a New Human-Centered Society. Japan SPOTLIGHT, 27(July / August), 47-50.

Keh, H. T. 1998. Evolution of The Book Publishing Industry: Structural Changes and Strategic Implications. Journal of Management History, 4(2), 104-123. https://doi.org/10.1108/13552529810219593

Lyons, S. 2004. An Exploration of Generational Values in Life and at Work. Carleton University.

Mangani, A., \& Tarrini, E. 2017. Who Survives A Recession? Specialization Against Diversification in The Digital Publishing Industry. Online Information Review, 41(1), 19-34. https://doi.org/10.1108/OIR-09-2015-0310.

Nashihuddin, W., \& Aulianto, D. R. 2017. Pengelolaan E-Conference dengan Aplikasi Open Conference System: Upaya Pengembangan Penerbitan Prosiding Online di Indonesia. Khizanah Al-Hikmah: Jurnal Ilmu Perpustakaan, Informasi, dan Kearsipan, 5(1), 29-49. https://doi.org/10.24252/kah.v5ila3.

Pew Research Center. 2010. Millennials: A Portrait of Generation Next. Confident. Connected. Open to Change. https://doi.org/10.1108/JCM-07-2013-0650.

PKP. 2008. OJS/OCS Quick Reference. California, USA: Creative Commons.

PKP. 2014. Open Conference Systems. Di https://pkp.sfu.ca/ocs/ (akses 26 Maret 2019).

Purbarani, S. C., Wisesa, H. A., \& Wibisono, A. 2015. Manajemen Pengelolaan Artikel pada International Conference on Advanced Computer Science and Information Systems (ICACSIS). Journal of Information Systems, 11(1), 45-52.

Purwadi, P., \& Irwansyah, I. 2019. Peran Public Information Officers dalam Komunikasi Layanan Perpustakaan Digital. BACA: Jurnal Dokumentasi dan Informasi, 40(55-72). https://doi.org/https://doi.org/10.14203/j.baca.v40i1.437

Rambatan, G. B. 2015. Ekonomi Kreatif: Rencana Pengembangan Penerbitan Nasional 20152019. Jakarta: PT. Republik Solusi.

Ramdhani, A., Rahmdhani, M.A., \& Amin, A.S. 2014. Writing a Literature Review Research Paper: A Step-By-Step Approach. International Journal of Basic and Applied Science, 3(1), 
$47-56$.

Ridwan, S.M. 2015. Application of Electronic Scholarly Publishing in Digital Age: Prospects and Challenges in Nigerian Universities. European Scientific Journal, 11(8), 263-278.

Schwab, K. 2016. The Fourth Industrial Revolution. World Economic Forum. Switzerland: World Economic Forum.

Siler, K. 2017. Future Challenges and Oppotunities in Academic Publishing. Canadian Journal of Sociology/Cahiers Canadiens de Sociologie, 42(1), 83-114.

Smith, T. J., \& Nichols, T. 2015. Understanding the Millennial Generation. Journal of Financial Service Professionals, 69(6), 11-14. https://doi.org/10.1109/EMR. 2011.5876176.

Velmurugan, C., \& Radhakrishnan, N. 2015. Electronic Publishing: A Powerful Tool for Academic Institutions in the Electronic Environment. International Journal of Library Science and Information Management (IJLSIM), 1(1), 10-18.

Willinsky, J., Stranack, K., Smecher, A., \& MacGregor, J. 2010. Open Journal Systems: A Complete Guide to Online Publishing. USA: Simon Fraser University Library. 